\title{
HOST RANGE PANTOEA ANANATIS THE CAUSAL AGENT OF BACTERIAL LEAF BLIGHT ON ALLIUM SPP.
}

\author{
Asrul $^{(1)}$, Umrah $^{2)}$ \\ ${ }^{1)}$ Faculty of Agriculture, Tadulako University, Email : asrul1203@gmail.com Jl. Soekarno-Hatta Km 9, \\ Palu Central Sulawesi, Indonesia 94118 \\ 2) Faculty of Mathematics and Life Sciences, Tadulako University. Jl. Soekarno-Hatta Km 9, \\ Palu Central Sulawesi, Indonesia 94118
}

\begin{abstract}
Bacterial leaf blight disease caused by Pantoea ananatis has been reported affects some species of Allium spp. Here, we determined the species of Allium spp. that are not the hosts of the P.ananatis through a host range test. The study designed as a completely randomized design with five replications. Pathogenic bacteria of $P$. ananatis inoculated to shallot, onion, spring onion, garlic, chives, leek, and cung spring onion in the greenhouse of the Faculty of Agriculture Tadulako University. The incubation period and symptoms of after inoculated by $P$. ananatis then observed. The results showed that four llium species (onion, onion, scallion, and garlic) were hosts of $P$. ananatis while the other three species (chives, leek, and cung spring onion) were not hosts of P. ananatis.
\end{abstract}

Keywords: Allium spp., Host range, Pantoea ananatis.

\section{INTRODUCTION}

Pantoea ananatis is a pathogen that causes bacterial leaf blight (Schwartz \& Gent, 2007). This pathogen attacks many economically important plants such as shallot, corn, melons, rice, pineapple, soybeans, wheat, mulberry, and rubber (Goszczynska et al., 2006; Ormsby et al., 2009) and caused severe damage (Schwartz $\&$ Mohan, 2008). The loss of the crop production has been reported reach up to $100 \%$ due to $P$. ananatis attacks in a favorable climatic condition (Nischwitzet al, 2007). Symptoms of leaf blight that caused by $P$. ananatis determined as watersoaked symptoms, wilting, white spots, necrotic and shoot death (Goszczynska et al., 2006). These symptoms look similar to the symptoms of bacterial leaf blight on shallots, which is knowns a new disease in Indonesia (Asrul, 2014). Infection that occurs in leaves able to spread to the tuber, which is known as a central rot disease (Eric et al., 2013). Therefore the pathogen can kill the plant rapidly.
Bactericide has been used widely by farmer since more practical with fast result. Chemically, the use of bactericide made from copper can suppress and control $P$. ananatisby spraying (Schwartz \& Gent 2007). However, if the use of chemicals is carried out intensively, it is likely that it will leave a bactericidal residue on the tuber. It residue can endanger the health of consumers when the shallot or onion tubers are processed as cooking spices, or food industry raw material. Besides, the use of chemicals is often not able to control all pathogens. Moreover, they will resist and may form a new race of pathogen and affect other beneficial microbes in the soil.

Therefore the strategy for controlling $P$. ananatisis directed to inexpensive and environmentally friendly. For example crop rotation with non-host plant rotation for three years or more can suppress the pathogen (Black et al., 2012). $P$. ananatis has never been reported to infect shallots, garlic, scallions, chives, leeks, and onions, so it is necessary to test 
the host range of the allium group. Information about the types of onions which are hosts of P. ananatis is essential because the habits of farmers are often found planting Allium crops in one family on the same land continuously. Also, a not host of $P$. ananatis in allium group can be used as a rotation plant to break out the pathogen life cycle. Subsequently, it reduces the chances of bacterial infection (Black et al., 2012). Here we determine the host of $P$. ananatisin the allium group. This study shows controlling pathogens preventively.

\section{METHODOLOGY}

The research was conducted at the Laboratory of Plant Pests and Diseases and the green house of the Faculty of Agriculture Tadulako University in January - May 2016. The experiment designed as a completely randomized design with five replications. A total of seven allium group crops were tested, which were shallot (Allium ascalonicum), onion (A. cepa var. Cepa), spring onion (A. fistulosum L.), garlic (A. sativum L.), chives (A. tuberosum), leek (A. porrum L.), and cung spring onion (A. schoenoprasum L.).

All allium species used where healthy seeds. A total of two tubers of allium seedling were grown in a pot containing sterile soil and organic compost $(3: 1, v: v)$. The seedlings then watered daily. A month after planted, the seedling inoculated with $P$. ananatis. The bacterial pathogen isolated from the shallot that infected in the field. The bacterial inoculum purified and grown on yeast peptone glucose agar (YPGA) media and incubated for 48 hours at room temperature.

Furthermore, the bacterial colony was suspended and propagated to $10^{8}$ $\mathrm{cfu} / \mathrm{ml}$ in Erlenmeyer. The inoculation of bacterial suspension to the shallots seedling followed by the method of Nunez et al. (2002) by spraying $10 \mathrm{ml}$ bacterial suspension per plant to the leaves that had previously been injured using a syringe. Visual symptoms on a leaf then observed daily, included wet spots, chlorotic, necrotic, shoot death, dwarf and bulging tubers. Observation documented every day from the initial inoculation to the appearance of symptoms.

\section{RESULTS AND DISCUSSIONS}

\section{Results}

The observation of the disease symptoms of Allium groupsin 14 days after inoculated showed that shallot, onion, spring onion, and garlic were infected by $P$. ananatis while chives, leek, and cung spring onion did not show any leaf blight symptoms. The incubation period on infected Allium spp. showed that there were differences in the time in symptoms appearance (Table 1). The symptoms of bacterial leaf blight in tested Allium spp. are in Figure 1 and Figure 2 respectively.

Table 1. Host Range of $P$. Ananatison Allium groups

\begin{tabular}{clcc}
\hline No. & Allium group & Infected (+) or not (-) & $\begin{array}{c}\text { Incubation } \\
\text { period (day) }\end{array}$ \\
\hline 1. & $\begin{array}{l}\text { Shallot (Allium cepa } \text { L aggregatum group/ } \\
\text { Allium cepa } \text { var. } \text { ascalonicum })\end{array}$ & + & 2.00 \\
2. & Onion (Allium cepa var. cepa $)$ & + & 3.00 \\
3. & Spring onion (A. fistulosum L.) & + & 3.33 \\
4. & Garlic (A. sativum L.) & + & 7.33 \\
5. & Cung spring onion (A. tuberosum) & - & - \\
\hline
\end{tabular}




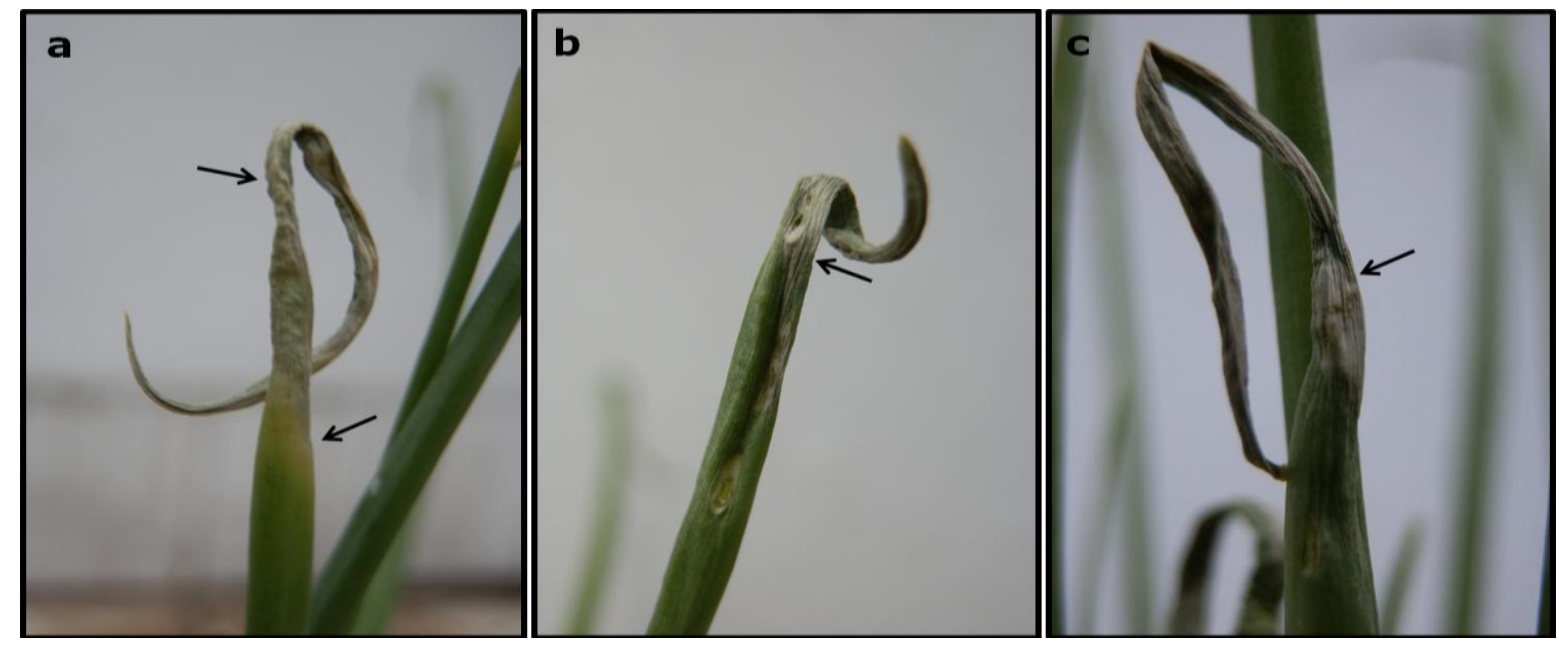

Figure 1. The symptoms of bacterial leaf blight in shallot. a) clhorotic and necrotic, b) . leaf tip rolled up, c) leaf curves downward (see arrows).
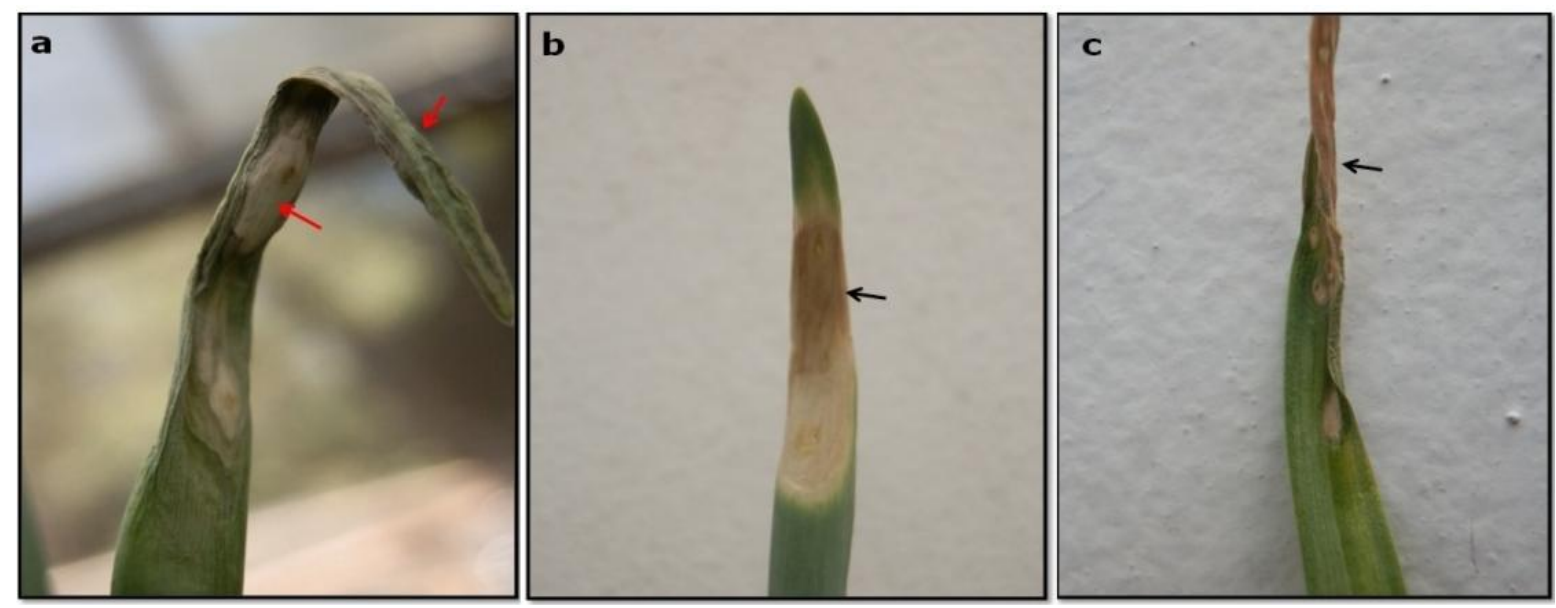

Figure 2. Symptoms of bacterial leaf blight in three Allium spp.: a) the tip of the onion leaf bend, shrink, necrotic and death on the shoot, b) white to brown necrotic appeared and dried at the point of infection on leaf tip, and slightly curves on the spring onion, c) brown necrotic spots at the point of infection until the leaf tip of garlic.

Discussion. In general, the host range of a pathogen can be broad or narrow depending on the pathogen. The pathogen-host range refers to the number of hosts that can be infected by the pathogen. The knowledge of the host range will help in controlling the pathogen in the early stage. This study showed that $P$. ananatisinfected shallot, onion, spring onion, and garlic with similar blight symptoms while chives, leek, and cung spring onion did not infect.

Severe leaves symptoms indicated that the Allium spp. were susceptible to the bacterial blight. The symptoms of bacterial leaf blight on shallot were water-soaked from the middle to the end of the leaf, wilt and wrinkled, the leaf curved and sometimes curled. The necrotic lines with brown and white color were noted on the leaf. The necrotic covered all of the leaf surfaces when many spots developed to the base of the leaf. Furthermore, leaf tissue dried and the shoot died (Figure 1a to 1c).

Infected onion showed soakedwater, wilt, and wrinkles, curved, and white necrotic symptoms (Figure 1a). Meanwhile, 
shallot symptoms included water-soaked, leaf slightly curved, brown or white necrotic occured, but did not wrinkle (Figure 1b). Infected garlic showed similar symptoms included chlorotic and wrinkled, the leaf color change to brown and a little leaf curved (Figure 1c). In line with the finding of Goszczynska et al. (2006), symptoms of bacterial leaf blight caused by $P$. ananatisis determined by water-soaked, wilted, chlorotic, necrotic and shoot death.

The ability of the pathogenic bacteria to cause symptoms of the disease is due to the occurrence of compatible interactions between virulent pathogens and vulnerable hosts. A compatible interaction between susceptible hosts and virulent pathogens will allow the pathogen penetration to the host cell wall, infect the host, and develop the disease. The results of this host range assay show that all infected plants are hosts of the bacterial leaf blight pathogen.

It has been reported that the infection process begins with contact between the pathogen and the host, followed by pathogen-host penetration. The $P$. ananatis bacteria are weak pathogens and enter the host plant only through wounds formed in the host due to the use of agricultural equipment during harvest or due to insect bites (McDonald et al., 2004), not through natural holes such as stomata, hydathode, honey gland, or lenticel. After pathogen penetrate from the host's surface into plant cells through wounds, then the bacteria move into the intercellular space in the leaf tissue. The bacteria, subsequently multiply themselves in the area between cells in the leaf, but bacteria do not grow in cells because the size of the bacteria is large enough to move between cells as a virus growth mode (Schumann \& D'Arcy, 2010). In plant tissues (intercellular), pathogens will obtain and utilize nutrients from cells of vulnerable plants so that pathogens develop (Agrios, 2005). In a favorable environmental condition, the disease symptoms such as water-soaked, wilted, chlorotic and necrotic will appear (Schumann \& D'Arcy, 2010).
The water soaked symptoms that appear on the surface of the allium leaves are influenced by the presence of extracellular polysaccharide (EPS) compounds secreted by pathogenic bacteria. $P$. ananatisare known to produce EPS (Morohoshi et al., 2007). The extracellular polysaccharide has been reported plays a role as a cause of water soaked symptoms in plant tissue infected by a pathogen (Habazar \& Rivai, 2004). When the intercellular space in leaf tissue filled with bacterial mass and forms extracellular polysaccharide, ion exchange becomes active with the release of $\mathrm{H}^{+}$into the intracellular space and the entry of $\mathrm{K}^{+}$into the intercellular space. Then, it causes an increase in $\mathrm{pH}$ from 5.5 to 7.5 so that it induces the release of sucrose, amino acids, and inorganic ions without damaging the structure of the plasma membrane. Additionally, EPS can reduce water flow through the primary cell wall in mesophyll tissue resulting in wilting leaf and causing necrotic (Habazar \& Rivai, 2004).

The emergence of symptoms of leaf blight on shallot, onion, spring onion, and garlic shows that the plant is in the host range of $P$. ananatis. Testing the host range is a way to find out which alternative host is used as a place to survive if the main host is not available. Information about alternative hosts is helpful to avoid planting allium group crops in one family simultaneously (intercropping), or side by side on the same land. Continuous planting of shallot or onion throughout the year on the same land preserve the presence of the pathogen.

Furthermore, the chive, leek, and cung spring onion tested in this study showed no infection after inoculation with $P$. ananatis. This indicates that $P$. ananatisbacteria was not able to develop in the plant tissue so that it did not cause any symptoms. It is suspected that the abovementioned Allium group are not hosts and do not belong to plants that are susceptible to $P$. ananatisinfection. Although chives, leeks, and cung onions sprig are still a family in the allium group, pathogens are not able to attack and infect plants, or 
pathogen may have entered leaf tissue then survive as an epiphyte but unable to cause a symptom. $P$. ananatishas also been reported act as epiphytes in leguminous crops but do not cause any symptoms of a disease (Coutinho \& Venter, 2009). Also, $P$. ananatisalso survive as epiphytes in weeds, cowpea, and soybeans, but also does not cause any disease symptom (Gitaitis et al., 2002). The inability of $P$. ananatisbacteria to infect chives, leeks and cung spring onion shows that these allium group it can be used for controlling pathogens as a rotational plant. The application of a rotational crop aims to escape the pathogen by eliminating the main host in a certain farming season. Subsequently, accumulation of the pathogenic is prevented.

The incubation period is the time that pathogens need to cause an initial symptom. The incubation period determines by the resistance of plant host to pathogenic infections, the virulence of the pathogen, and the environmental condition that support pathogen growth and develop (Agrios, 2005). In this study, the appearance of symptoms of bacterial leaf blight on the shallot as the main host was faster than onion, spring onion, and garlic. It is assumed that it is influenced by the resistance reactions of different allium group. The active resistance of the plant will be expressed if there is one inducing agent such as chemicals, biological substances, wounds or pathogenic infections. Pathogen infections can stimulate plants to produce phenolic compounds, peroxidase, or salicylic acid which play a role in plant resistance. In this case, the concentration of antimicrobial compounds may lower in shallots than onions, spring onion, and garlic. Therefore the pathogen suppressed slower and eventually the disease symptoms rapidly appear. The formation of phenol compounds, peroxidase, and salicylic acid as active defense responses of plants against pathogenic have been deported by Wijayanti et al. (2017). The accumulation of phenolic compounds in leaf tissue of plants is often associated with plant resistance to disease (Hua et al., 2014). The presence of phenol compounds plays an important role in increasing the resistance of plant leaves to pathogenic infections (Conti et al., 1986). Shallot that infected by pathogen increases the peroxidase enzyme activity in response to injury or invasion by a pathogen (Resti et al., 2016). The presence of the alternate host has to be observed that potentially maintain the presence of $P$. ananatis in the long term.

\section{CONCLUSION}

Chive, leek, and cung onion spring were not the host of $P$. ananatisso that they can be used as a rotation crop for the family of other susceptible Allium groups in the same farming area. This study suggests suppressing the presence of the pathogen in the previous planting season is possible by eliminating the availability of hosts during the next season with a non-host crop.

\section{BIBLIOGRAPHY}

Agrios, N. G. 2005. Plant Pathology- Fifth Edition. Departemen of Plant Pathology. University of Florida. United States of America

Asrul, 2014. Distribusi Dan Identifikasi Bakteri Patogenik Bawang Merah di Beberapa Sentra Produksi di Indonesia. Disertasi. Universitas Gadjah Mada, Yogyakarta.

Black, L., Conn, K., Gabor, B., Kao, J. \& Lutton, J. S. 2012. Onion Disease Guide: a Practical Guide for Seedmen Growers and Agricultural Advisors. Seminis Vegetable Seeds, Inc., USA.

Conti, G. G., Bassi, M., Maffi, D. \& Bocci, A. M. 1986. Host-parasite relationship in a susceptible and a resistant rose cultivar inoculated with Sphaerothecapannosa. Phytopathology, 117: 312-320. 
Coutinho, T. A. \& Venter, S. N. 2009. Pantoea ananatis: an unconventional plant pathogen. Molecular Plant Pathology, 10: 325-335.

Eric A. Carr, E. A., Zaid, A. M., Bonasera, J. M., Lorbeer, J. W. \& Beer, S. V. 2013. Infection of onion leaves by Pantoea ananatis leads to bulb infection. Plant diseases, 94 (7): 916.1 916.2

Gitaitis, R., Walcott, R., Culpepper, S., Sanders, H., Zolobowska, L. \& Langston, D. 2002. Recovery of Pantoea ananatis, causal agent of center rot of onion, from weeds and crops in Georgia, USA. Crop Protection, 21: 983 - 989.

Goszczynska, T., Moloto, V. M., Venter, S. N. \& Coutinho, T. A. 2006. Isolation and identification of Pantoea ananatis from onion seed in South Africa. Seed Science Technol 34: 655668.

Habazar, T. \& Rivai, F. 2004. Bakteri Patogenik Tumbuhan. Andalas University Press, Padang.

Hua, Y., Guo, H., Xin-Gen Zhou, Xiao Li, Yang, S., Song, Y., Ning Ma, C. Chai, Xin Qiao \& L. $\mathrm{Li}, 2014$. Correlations between soluble sugar and phenol contents in leaves and Pear scab resistance. Journal of Plant Pathology \&Microbiology, 5 (1): 1 - 4

McDonald, M. R, Jaime \& Hovius, M. H.Y. 2004. Management of Diseases of Onions and Garlic. In: Naqwi, S. A. M. 2004. Diseases of fruiets and vegetables: diagnosis and management. Kluwer Academic Publishers. The Netherlands. 149 - 200 pp.

Morohoshi, T., Oseki, K \& Ikeda, T. 2011. Exopolysaccharide production is influenced by sugars, $N$-Acylhomoserine lactone, and transcriptional regulators Rcs $A$ and Rcs B, but does not affect pathogenicity in the plant pathogen Pantoea ananatis. Bioscience Biotechnology Biochemystri, 75: 997 - 999.

Nischwitz, C., Gitaitis, R., Sanders, H., Langston, D. B., Mullinix, B.,Torrance, R., Boyhan, G., \& Zolobowska, L. 2007. Use of fatty acidmethyl ester profiles to compare coppertolerant and copper sensitivestrains of Pantoea ananatis. Phytopathology 97:12981304.

Nunez, J. J., Gilbertson, R. L., Meng, X. \& Davis, R. M. 2002. First report of Xanthomonas leaf blight of onion in California. Plant Disease 86 (3): 137 - 142

Ormsby, M., Pottinger, B., Jones, D., Martin, N. \& Fullerton, B. 2009. Import Risk Analysis: Onion (Allium cepa Liliaceae) Fresh Bulbs for Consumption from China. Wellington New Zealand. $49 \mathrm{p}$.

Resti, Z., Habazar, T., Putra, D.P., \& Nasrun. 2016. Aktivitas enzim peroksidase bawang merah yang diintroduksi dengan bakteri endofitdan tahan terhadap penyakit hawar daun bakteri (Xanthomonas axonopodis pv. allii). Jurnal HPT Tropika 16(2): 131 - 137.

Schumann \& D'Arcy. 2010. Essential Plant Pathology. Second Edition. The American Phytopathological Society. St. Paul, Minnesota, USA.

Schwartz, H. F. \& D. H. Gent. 2007. Onion : Pantoea Leaf Blight and Center Rot. Colorado State University Extension. Colorado Onion Production and Integrated Pest Management.High Plains IPM Guide.

Schwart, H. F. \& Mohan, S. K. 2008. Compendium of Onion and Garlic Disease and Pests. 2nd Ed. American Phytopathologycal Society, St. Paul. MN. 
Wijayanti, K. S., B. T. Rahardjo, dan T. Himawan, 2017. Pengaruh Rizobakteri dalam Meningkatkan Kandungan Asam Salisilat dan Total Fenol Tanaman Terhadap Penekanan Nematoda Puru Akar. Buletin Tanaman Tembakau, Serat dan Minyak Industri 9(2): $53-62$. 